\title{
Structural evolution of the Nojima fault (Awaji Island, Japan) revisited from the GSJ drill hole at Hirabayashi
}

\author{
Anne-Marie Boullier ${ }^{1}$, Koichiro Fujimoto ${ }^{2},{\text { Hisao } \text { Ito }^{3} \text {, Tomoyuki Ohtani }}^{4}$, Nynke Keulen ${ }^{5}$, \\ Olivier Fabbri ${ }^{6}$, David Amitrano ${ }^{7}$, Michel Dubois ${ }^{8}$, Philippe Pezard $^{9}$ \\ ${ }^{1}$ L.G.I.T.-CNRS, Joseph Fourier University, Grenoble, France \\ ${ }^{2}$ Tokyo Gakugei University, Japan \\ ${ }^{3}$ Geological Survey of Japan, AIST-Earthquake Research Group, Tsukuba, Japan \\ ${ }^{4}$ Gifu University, Japan \\ ${ }^{5}$ Department of Earth Sciences, Basel University, Switzerland \\ ${ }^{6}$ Franche Comté University, Besançon, France \\ ${ }^{7}$ ENS Mines Nancy, France \\ ${ }^{8}$ Department of Earth Sciences, Lille University, France \\ ${ }^{9}$ ISTEEM, Montpellier University, France
}

(Received May 25, 2004; Revised November 19, 2004; Accepted December 1, 2004)

Following the Hyogoken Nanbu earthquake (January 17, 1995, Mw=7.2), three drillholes were sunk through the Nojima Fault (Awaji Island, Japan). Textural and petrographic studies of the Geological Survey of Japan (GSJ) drill cores allow recognition of two deformation episodes. The first one is older than the deposition of the Middle to Late Eocene Kobe Group, corresponds to a left-lateral movement on the Nojima fault and is expressed by pseudotachylytes, kinking of biotite crystals in the low-strain rocks and an intense laumontite hydrothermal alteration. The second one displaces the basal unconformity of the Kobe group, corresponds to a right-lateral reverse displacement and is expressed at least by carbonate-filled hydraulic fractures and thin gouge zones. Different important deformation mechanisms are recorded by the fault rocks, but questions relating to the attribution of deformation and alteration features to one or other deformation episodes remain unresolved.

Key words: Nojima, fault, seismic, aseismic, deformation, veins, laumontite, carbonates.

\section{Introduction}

The Nojima fault (Awaji Island, Japan) has been extensively studied after the Hyogo-ken Nanbu earthquake (January 17, 1995, Mw=7.2). Three drill holes (drilled by GSJ, NIED and University group) have encountered the fault at different depths and have allowed structural observations of the fault imprint on the surrounding rocks. This paper summarizes the results of a textural and petrographic study of the drill cores from the GSJ borehole, and points out the different important mechanisms recorded by the fault rocks and some unresolved questions.

\section{The Geodynamic Context of the Nojima Fault}

The Nojima fault has a $\mathrm{N} 45^{\circ} \mathrm{E}$ orientation and a subvertical dip $\left(85^{\circ} \mathrm{SE}\right)$. Left-lateral transcurrent faults with identical $\mathrm{N} 45^{\circ} \mathrm{E}$ orientation were formed in southwest Japan during the Late Cretaceous-Palaeocene (Kanaori, 1990) and are interpreted to belong to a fault network defining a regional block structure. Reactivation of these faults occurred in pre5 Ma times (left-lateral) and in Late Pliocene to Quaternary times (right-lateral) (Fig. 1; Fabbri et al., 2004).

In the Awaji Island (Fig. 2), the Nojima fault cross-cuts the Cretaceous Nojima granodiorite (K-Ar ages on miner-

Copy right(c) The Society of Geomagnetism and Earth, Planetary and Space Sciences (SGEPSS); The Seismological Society of Japan; The Volcanological Society of Japan; The Geodetic Society of Japan; The Japanese Society for Planetary Sciences; TERRAPUB als ranging from 70 to $90 \mathrm{Ma}$, Takahashi, 1992; cooling age at $74 \pm 3$ Ma by zircon fission track method, Murakami and Tagami, 2004) and its porphyry dykes. The granodiorite is unconformably overlain by the Kobe Group, the base of which has been dated to Middle to Late Eocene (Yamamoto et al., 2000), and by the Plio-Pleistocene Osaka Group (Murata et al., 2001). The Quaternary vertical offset is 490 to $540 \mathrm{~m}$ as determined by the vertical displacement of the Kobe Group basal unconformity (Murata et al., 2001). The corresponding average slip rate $\left(0.4-0.5 \mathrm{~m} / 10^{3}\right.$ years downdip and $0.9-1.0 \mathrm{~m} / 10^{3}$ years right-lateral) of the Nojima fault has been estimated by Mizuno et al. (1990).

Studies of deformation and alteration textures indicate that the fault damage zone is $>46.5 \mathrm{~m}$ wide and the fault core itself is $30 \mathrm{~cm}$ wide (Ohtani et al., 2000, 2001; Tanaka et al., 2001; Fujimoto et al., 2001). However, if the Nojima fault has followed the same two-stage evolution of the $\mathrm{N} 45^{\circ} \mathrm{E}$ fault system, the present-day thickness of the fault is the result of deformation accumulated over its whole history and it is important to understand what are the deformation and alteration structures related to each episode. In order to decipher this two-stage history, it should be pointed out that deformation structures related to the recent activity of the fault could not have formed at a depth greater than the present-day depth of the sample within the drill hole plus the Quaternary 490-540 m vertical offset. Conversely, any structure formed at a depth greater than the present-day 


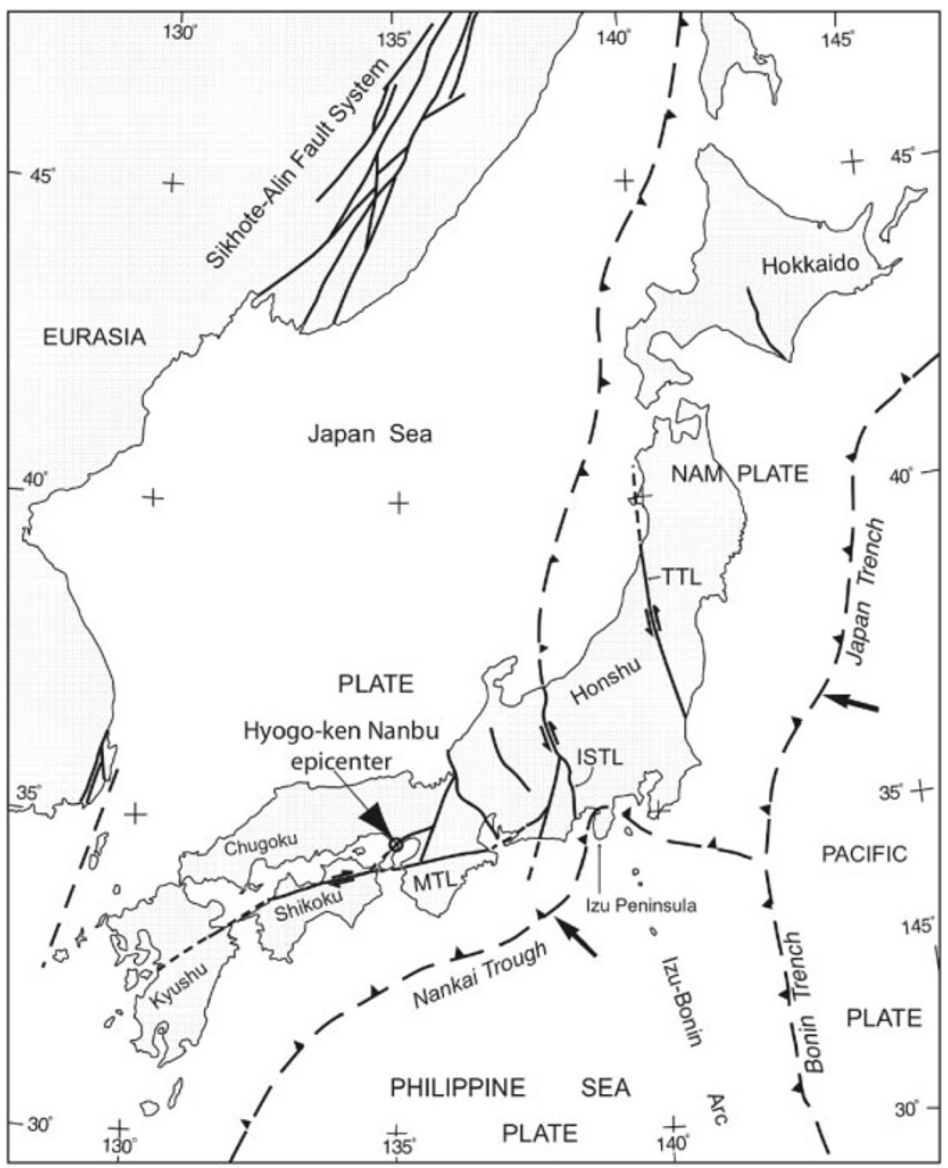

Fig. 1. Tectonic framework of Japan with localization of the Hyogo-ken Nanbu earthquake epicenter on the Nojima fault.
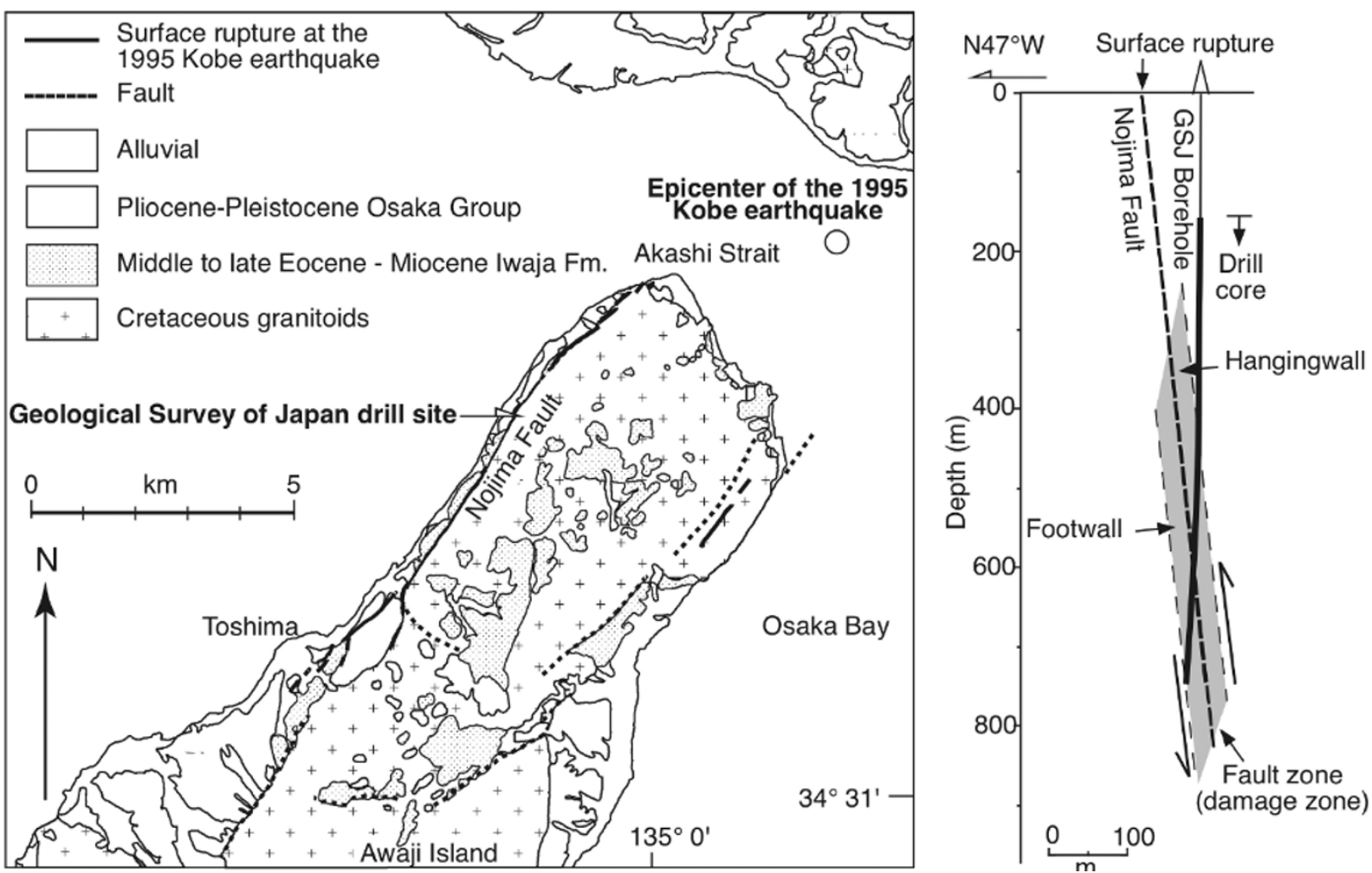

Fig. 2. Geological map of the Awaji Island and sketch of the Hirabayashi borehole showing the relative orientations of the fault and borehole (after Ohtani et al., 2000). The shaded pattern on the sketch represents the fault zone (i.e. damage zone). 


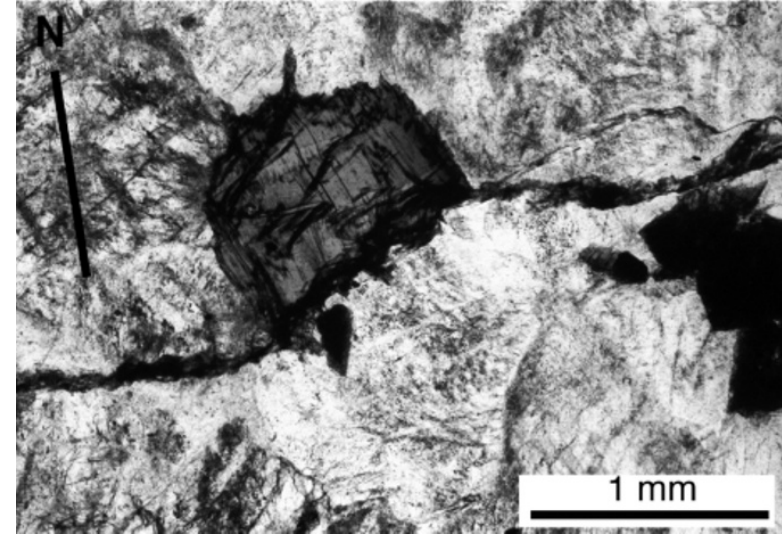

Fig. 3. Microphotograph of shortened cleavages in biotite in an oriented horizontal thin section at $352 \mathrm{~m}$ depth. North is indicated by the thick black line Note also the black trace of a fracture acting as a dissolution or stylolite-like plane.

depth of the sample within the drill hole plus the Quaternary 490-540 m vertical offset should have been formed before the displacement of the Kobe Group basal unconformity.

\section{Microstructural Studies of the Fault Rocks}

\subsection{Low strain rocks}

Outside the fault zone, the granodiorite may appear as undeformed. However, careful observations indicate that some strain is recorded in these rocks. Two directions of horizontal shortening are observed in the Nojima granodiorite in the GSJ borehole. They can be deduced from the orientation of fluid inclusion planes (mode I cracks), and kinkbands in quartz and biotite (Fig. 3). Following Boullier et al. (2000), the first shortening event recorded by kinked cleavage planes in biotites (Fig. 4) is NNW-SSE orientated and coincides with the principal orientation of fluid inclusion planes (Takeshita and Yagi, 2000), and with cracks sealed by albite and chlorite. Consequently, they probably appeared in greenschist facies conditions (around $300^{\circ} \mathrm{C}$ ). Takeshita and Yagi (2000) suggest that this first shortening event, which is consistent with a left-lateral movement on the $\mathrm{N} 45^{\circ} \mathrm{E}$ Nojima fault, occurred in Late Cretaceous times (around $85 \mathrm{Ma}$ ) just after the solidification of the granodiorite.

\subsection{Pseudotachylytes}

Pseudotachylytes are observed in the fault core (Ohtani et al., 2000, 2001; Tanaka et al., 2001; Boullier et al., 2001; Otsuki et al., 2003). They are closely related to some fine-grained fault gouges (Otsuki et al., 2003), which are characterized by an isotropic or homogeneous texture without any strain localization (no shear plane), and have experienced fluidization (Otsuki et al., 2003).

Boullier et al. (2001) described fluid inclusions within pseudotachylytic glass in the fault core at $624.59 \mathrm{~m}$ in the GSJ drill hole. The fluid inclusions are filled with a high density $\mathrm{H}_{2} \mathrm{O}+\mathrm{CO}_{2}$ fluid. Isochoric lines calculated from these fluid inclusions (Fig. 5) indicate that they were formed at a minimum depth of $15 \mathrm{~km}$ for a $24^{\circ} \mathrm{C} / \mathrm{km}$ geothermal gradient (Kitajima et al., 1998; Yamaguchi et al., 1999) or $10 \mathrm{~km}$ if a slightly higher $30^{\circ} / \mathrm{km}$ geothermal gradient is chosen. Consequently, the pseudotachylytes which con-
Orientations of kinked (001) planes in biotites

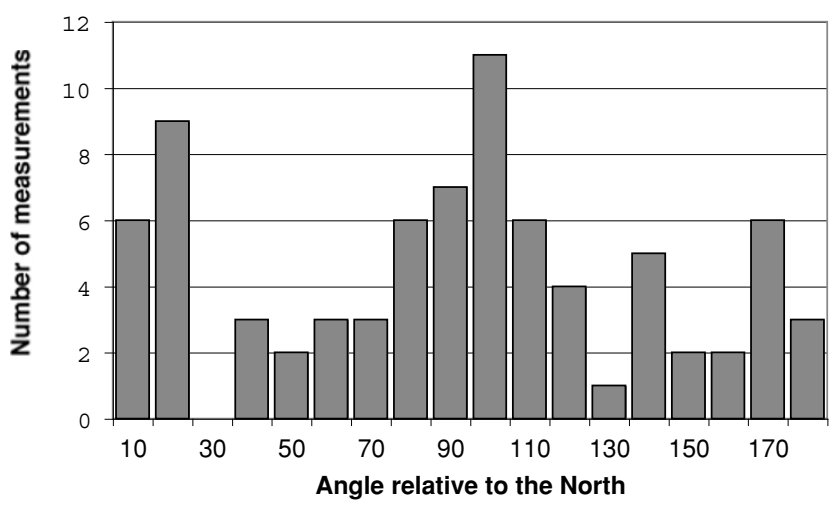

Fig. 4. Histogram of the orientation of shortened biotite cleavage planes relative to the North in the thin section shown in Fig. 3 at $352 \mathrm{~m}$ depth. Two maxima are observed at N15E and N100E respectively.

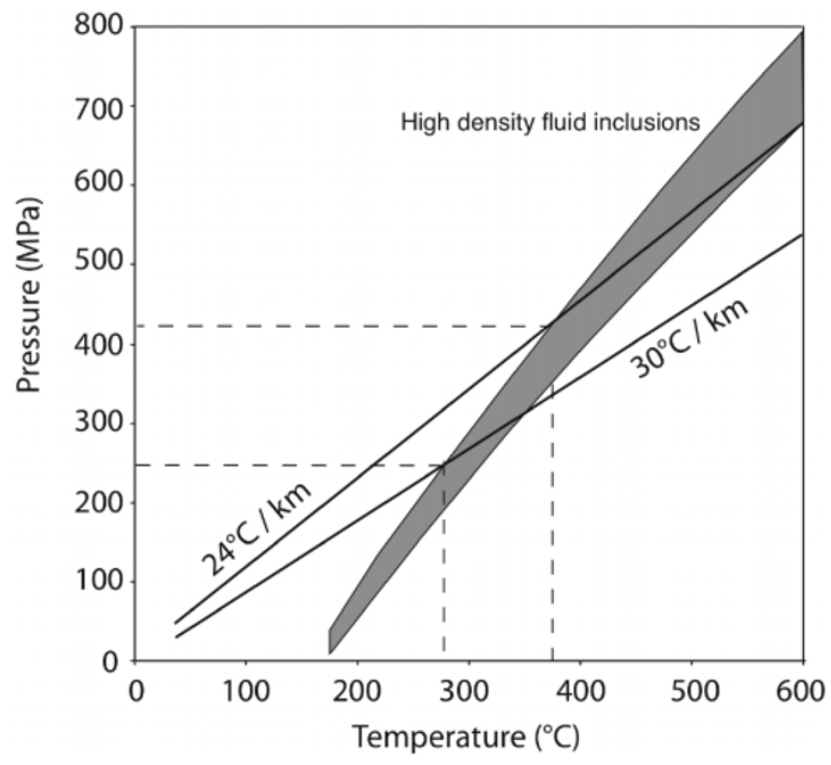

Fig. 5. Isochoric lines calculated from the microthermometric data on fluid inclusions in pseudotachylytes, after Boullier et al. (2001).

tain these fluid inclusions and which originated by friction melting during earthquakes were interpreted to have formed in greenschist facies P-T conditions at depths greater than $10 \mathrm{~km}$ and temperatures higher than $280^{\circ} \mathrm{C}$. Therefore, the pseudotachylytes and the associated fine-grained ultracataclasites cannot correspond to the Quaternary activity of the Nojima fault. These events have been interpreted to have occurred after the solidification of the granodiorite but before the deposition of the Kobe Group (Boullier et al., 2001), that is some time between $80 \mathrm{Ma}$ and $40 \mathrm{Ma}$. Recent dating of pseudotachylyte at $56 \pm 4 \mathrm{Ma}$ using the zircon fission-track method (Murakami and Tagami, 2004) confirms our assumption and confirms previous fission-track data obtained on GSJ borehole samples indicating that the rocks around the fault have been reheated around 30-40 Ma ago, well after the initial cooling of the granodiorite to $210^{\circ}-310^{\circ} \mathrm{C}$ that occurred at $74 \pm 3 \mathrm{Ma}$ (Murakami et al., 2002). 

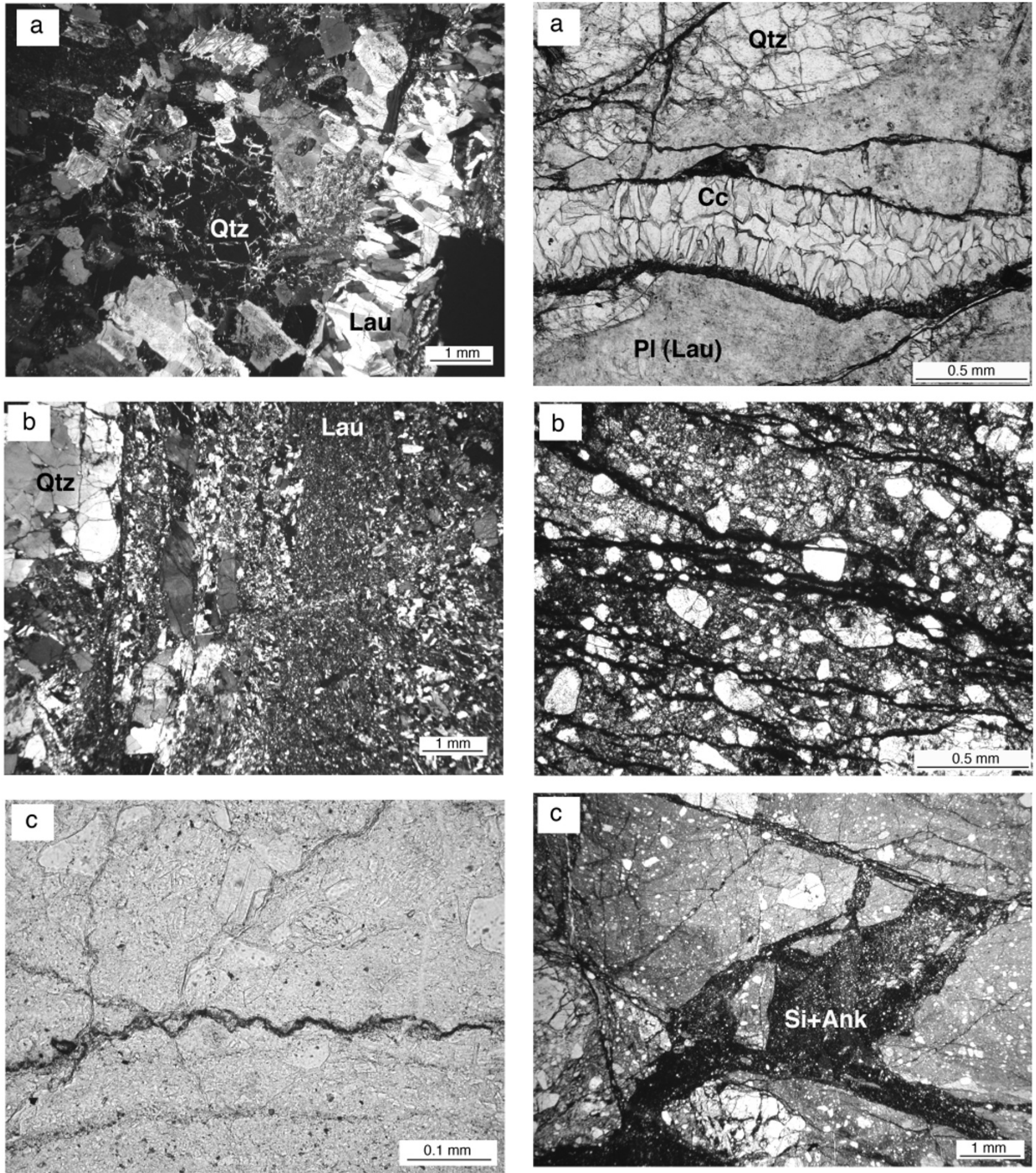

Fig. 6. Textural features in laumontite veins. (a) Blocky internal structure in a fractured granodiorite at $659.45 \mathrm{~m}$ depth; note the fractured quartz grain (Qtz, black in the center) cemented by laumontite. Crossed polars. (b) Fine-grained hydraulic fracture containing fragments of surrounding minerals in a matrix of very fine-grained laumontite (Lau, $588.75 \mathrm{~m}$ depth, crossed polars). (c) Stylolite developed in the fine-grained laumontite matrix of a hydraulic fracture $(586.50 \mathrm{~m}$ depth). The orientation of the stylolite is subvertical and parallel to the fault plane.

\subsection{Hydrothermal alteration}

Ohtani et al. (2000) and Fujimoto et al. (2001) distinguished three major episodes of hydrothermal alteration within the fault granodioritic wall rocks in the GSJ drill hole. These episodes are characterized successively by

Fig. 7. Textural features in carbonate veins. (a) blocky calcite (Cc) vein in a fractured and altered granodiorite $(501 \mathrm{~m}$ depth). Note the fractured quartz grains (Qtz) and the plagioclase $(\mathrm{Pl})$ entirely replaced by laumontite (Lau). (b) Very thin siderite veinlets cross-cutting a compacted cataclasite. The actual orientation of the veinlets is subvertical and parallel to the fault plane $(623.50 \mathrm{~m}$ depth). (c) Fine-grained hydraulic fracture (black on the microphotograph) containing fragments of the surrounding cataclasite in a matrix of very fine-grained siderite and ankerite ( $\mathrm{Si}+\mathrm{Ank}, 623.50 \mathrm{~m}$ depth). Same sample as in Fig. 7(b).

chlorite, zeolite and then carbonates. Some clays have also been observed within the fault at Hirabayashi village (Otsuki et al., 2003) and detected by X-ray diffraction in the core samples (Fujimoto et al., 2001) but will not be de- 
Table 1. Principal occurrences and features of the hydrothermal minerals in the GSJ drillhole.

\begin{tabular}{|c|c|c|c|c|}
\hline Mineral & Chlorite & Zeolite: laumontite & Siderite & Carbonate \\
\hline Stability field & ca. $300^{\circ} \mathrm{C}$ & ca. $150-280^{\circ} \mathrm{C}$ & & less than $100^{\circ} \mathrm{C}$ \\
\hline Texture & \begin{tabular}{|} 
as rosettes in small \\
cavities \\
in cracks with \\
albite
\end{tabular} & $\begin{array}{l}\text { in veins, blocky coarse- } \\
\text { grained filling } \\
\text { in hydraulic fractures, with } \\
\text { small fragments of } \\
\text { cataclasites or minerals }\end{array}$ & $\begin{array}{l}\text { in thin veinlets parallel } \\
\text { to the flattening plane } \\
\text { within the fault core }\end{array}$ & $\begin{array}{l}\text { calcite:blocky coarse-grained veins, with } \\
\text { scarce analcite } \\
\text { in hydraulic fractures close to the fault } \\
\text { core, with fragments of cataclasite or } \\
\text { mineral (ankerite and siderite) }\end{array}$ \\
\hline $\begin{array}{l}\text { Alteration } \\
\text { product }\end{array}$ & $\begin{array}{l}\text { alteration of biotite } \\
\text { and amphibole }\end{array}$ & $\begin{array}{l}\text { in-situ replacement product } \\
\text { of plagioclase }\end{array}$ & & $\begin{array}{l}\text { alteration product of plagioclase, biotite } \\
\text { and amphibole }\end{array}$ \\
\hline $\begin{array}{l}\text { Mechanisms of } \\
\text { formation }\end{array}$ & & hydraulic fracturation & Taber growth & hydraulic fracturation \\
\hline $\begin{array}{l}\text { Subsequent } \\
\text { deformation }\end{array}$ & & $\begin{array}{l}\text { dissolution processes: } \\
\text { stylolites } \\
\text { brecciation in the fault zone }\end{array}$ & brecciation & $\begin{array}{l}\text { dissolution processes: stylolites and } \\
\text { schistosity } \\
\text { brecciation and comminution in thin fine- } \\
\text { grained gouge zones }\end{array}$ \\
\hline $\begin{array}{l}\text { Suggested } \\
\text { relative age }\end{array}$ & $\begin{array}{l}\text { prior to the Kobe } \\
\text { Group deposition }\end{array}$ & $\begin{array}{l}\text { prior to the Kobe Group } \\
\text { deposition }\end{array}$ & quiescence stage & Quaternary to recent \\
\hline
\end{tabular}

scribed in this study. Table 1 gives the principal occurrences and features of these hydrothermal minerals.

The structures accompanying laumontite alteration are very similar to those described by Blenkinsop and Sibson (1992) in the Cajon Pass drill hole. First, laumontite veins with straight boundaries and blocky internal structures (Bons, 2000) are observed in the whole drill hole (Fig. 6(a)). Then, hydraulic fractures occur where angular fragments of neighbouring minerals or cataclasites are embedded in a fine-grained matrix of laumontite (Fig. 6(b)). Laumontite is the main product of transformation of plagioclase and a common infill of fractures within quartz (Fig. 6(a)). Similarly, blocky calcite veins are also observed in the drill hole (Fig. 7(a)) and are clearly later than laumontite.

Within the fault zone, very thin siderite veinlets are parallel to the fault plane (Fig. 7(b)) and postdate the veins described above. They display fibrous internal structure and may have formed by "Taber-growth" (Means and Li, 2001). Above the fault core, these siderite veinlets are crosscut by hydraulic fractures showing jigsaw contours and fragments of neighbouring minerals or cataclasites in a mixture of euhedral ankerite and siderite crystals (Fig. 7(c); Boullier et al., 2004). The fine-grained laumontite and carbonate veins display deformation structures such as stylolites or dissolution features (Fig. 6(c); Boullier et al., 2004, figures 9 and $10)$.

The similarity of textures suggests that zeolites and carbonates may be attributed to comparable hydrothermal and deformation processes that occurred at different depths and temperatures. The succession (1) laumontite, (2) calcite \pm analcite, (3) siderite \pm ankerite can be deduced from thin sections observations. This mineralogical succession is consistent with decreasing temperature conditions by comparison with hydrothermal alteration parage- neses in Cajon Pass (James and Silver, 1988; Vincent and Ehlig, 1988). The stability field of laumontite could be estimated between $150^{\circ} \mathrm{C}$ and $280^{\circ} \mathrm{C}$ depending on the pressure (Zen and Thompson, 1974). The presence of laumontite within pseudotachylyte-associated ultracataclasites has been demonstrated by X-ray diffraction (Otsuki et al., 2003). All together, these observations suggest that laumontite alteration as well as friction melting should be related to the first stage of the structural evolution of the Nojima fault.

In contrast, the carbonate-filled hydraulic fractures are compatible with the composition of the fluid which is presently percolating through the fault (Sato and Takahashi, 1999) and, therefore, may have been formed during the Quaternary activity of the Nojima fault (Boullier et al., 2004). The siderite veinlets which are younger than laumontite alteration but older than carbonate-filled hydraulic fractures, could have formed during the quiescent period between the two stages of deformation on the Nojima fault.

\subsection{The latest events: thin fault gouge zones}

The youngest structures observed in the GSJ borehole are symptomatic of two types of deformation processes: pressure solution expressed by dissolution features (stylolites, Fig. 6(c)) and brecciation/comminution expressed by thin fault gouges which are especially numerous below the fault core (i.e. in 625-635 $\mathrm{m}$ interval in the GSJ borehole). These two processes correspond to very low and high strain-rate mechanisms respectively and may tentatively be attributed to interseismic and seismic periods, although a controversy still exists on the seismic or aseismic character of cataclasites and gouges (see the review by Snoke and Tullis, 1998). In order to understand the deformation processes within the gouge zones (comminution, compaction, dissolution, recrystallization), the $2 \mathrm{D}$ grain-size distribution has been measured (Fig. 8(a)) in fault rocks using back-scattered 

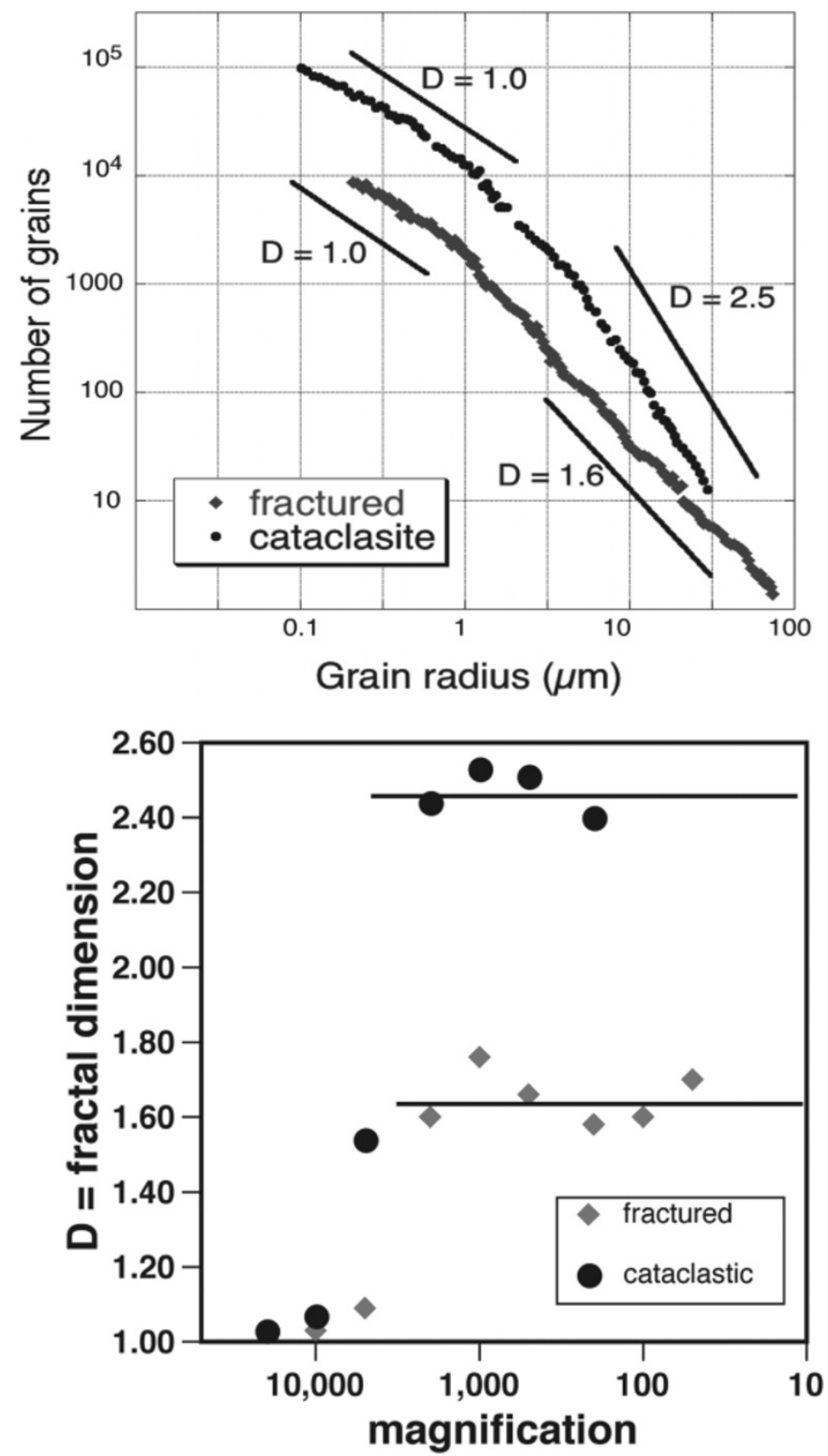

b

Fig. 8. (a) Grain size distribution obtained from SEM-images of thin sections of fractured rocks (522.88 $\mathrm{m}$ depth) and of cataclasites (624.41 m depth). The negative of the slope is the fractal dimension, D. (b) Variations of D values for fractured rocks $(522.88 \mathrm{~m}$ depth) and cataclasites (624.41 m depth) as a function of the magnification of the images. A high magnification relates to a small grain size. The cataclasites have a higher $\mathrm{D}$-value (2.5) than the fractured grains (1.6).

SEM images with different magnifications. With help of the public domain software ImageJ (http://rsb.info.nih.gov/ij/), grain boundary maps were drawn using a combination of automatic and manual grain boundary tracing. For automatic tracing a method similar to that described by Heilbronner (2000) was used. The grain size in Fig. 8 is the equivalent radius of a circle having the same area as the grain. An image at $\times 100$ magnification covers an area of $11 \mathrm{~mm}^{2}$. For each sample at each magnification, at least 500 grains were counted. For the grain size distribution of the rock, we have distinguished fractured fault rocks in which the fragments or counterparts could be fitted together (522.88 $\mathrm{m}$ depth), from the cataclasites in which counterparts cannot be identified (624.41 m depth). The grain size distribution can also be displayed as magnification of the images versus the fractal dimension (D-value) observed in each image (Fig. 8(b)). On these figures $(8(a)$ and $8(b))$ it appears that:

- for large grain sizes (low magnifications) the D values are 1.6 for fractured rocks and 2.5 for cataclasites.

- for small grain sizes (high magnifications) the slope of the distribution approaches 1 in both cases.

- the pinning point between large and small grain sizes is close to the grinding limit (1.7 $\mu \mathrm{m}$ diameter for quartz; Prasher, 1987).

- much smaller particles than the grinding limit are observed (ca. $50 \mathrm{~nm}$ ). 
Blenkinsop (1991) has studied the grain size distribution and fractal dimension of cataclastic granitoid samples from the Cajon Pass drilling project. These granitoid cataclasites originate from various depths, up to $2807 \mathrm{~m}$ and have 2D fractal dimensions of 0.88-2.08. The fractal dimensions we found are higher, possibly because our samples were deformed later again during a subsequent episode, or because we analyzed more grains and studied a wider range of smaller grain sizes. Our results for the pseudotachylyte-related ultracataclasites of the Nojima fault (624.41 m depth) are comparable to the observations of Monzawa and Otsuki (2003), who studied the grain size distribution of larger grains for the Nojima and three other fault zones. We were able to measure the sizes of the very small grains with the Scanning Electron Microscope. These grains have a diameter that is much smaller than the grinding limit. Therefore, grinding is not the only effective mechanism to decrease the grain size. Abrasion or dissolution might be involved in the grain size reduction of the smallest particles. We report higher $\mathrm{D}$ values for cataclasites (2.5) than for fractured fault rocks (1.6) within the Nojima fault. The difference may be due to increasing strain or variations in confining pressure (Amitrano and Schmittbuhl, 2002) or to additional active processes in cataclasites such as fluidization as suggested by Monzawa and Otsuki (2003). However, more measurements are needed on different types of fault rocks in order to test the response of the grain size distributions to quiescent periods during which compaction or recrystallization mechanisms may occur as suggested by studies of experimental and naturally deformed fault rocks (Keulen et al., 2003a, b).

Since they are the youngest observed deformation structures in the drill hole, the thin gouge zones are tentatively attributed to recent and near-surface seismic activity.

\section{Remaining Questions and Conclusions}

The Nojima fault has undergone a multistage evolution. At least two main periods can be distinguished. The first one occurred before the deposition of the Kobe Group $(<40$ $\mathrm{Ma})$ and before the uplift of the granodioritic basement. The second (Late Pliocene to Quaternary) corresponds to the 490 to $540 \mathrm{~m}$ vertical offset of the unconformity at the base of the Kobe Group. Therefore, the structures observed in the drill hole can be attributed to either one or the other period.

Given our data and observations, the imprint of the first period is represented by the pseudotachylytes and a NNESSW compressional event expressed by shortened biotite cleavage planes and healed fluid inclusion planes. The later structures correspond to a sinistral strike-slip movement on the Nojima fault. As laumontite is stable between 150 and $280^{\circ} \mathrm{C}$ (Zen and Thompson, 1974), it was probably formed also prior to the deposition of the Kobe Group and, therefore, it is tentatively related to the first period. If friction melting (pseudotachylytes) and laumontite alteration were contemporaneous at ca. $56 \mathrm{Ma}$ (Murakami and Tagami, 2004), it means that the temperature deduced from fluid inclusions in pseudotachylytes $\left(>280^{\circ} \mathrm{C}\right.$, Boullier et al., 2001) may have been slightly overestimated.

On the basis of similar composition between carbonate infill and the fluid sampled in the fault after drilling, Boullier et al. (2004) have interpreted the carbonate-filled hydraulic fractures as due to co-seismic circulation of fluids during Quaternary or Recent activity of the fault. Consequently, the thin gouge zones being younger than the carbonate hydraulic fractures are themselves attributable to the latest period of activity of the Nojima fault.

Thickness of the fault zone $(>46.5 \mathrm{~m})$ is determined from alteration and deformation features (Tanaka et al., 2001; Ohtani et al., 2000) and most of the width of the fault is characterized by laumontite alteration (Fujimoto et al., 2001). Therefore, there is no correlation between the present-day width of the fault zone and the measured vertical Quaternary (ca. $500 \mathrm{~m}$ ) movement and this set of data should be used with caution to assess a relationship between thickness of the gouge zone and total displacement along faults (Scholtz, 1990).

Some questions remain: should we consider some quiescent intervals between the major periods of activity? If yes, what could be the textures indicative of this quiescence? Significant changes in the fluid composition percolating through the fault probably occurred between the laumontite and the carbonate episodes. Could it be correlated with a change in the origin or the main fluid reservoirs or with different circulation or mixing paths?

If it is often possible to interpret the different structures observed in the fault zone in terms of low or high strain rate processes, it is still difficult, if not impossible, to interpret them in terms of kinetics or dynamics. What is the duration of the aseismic intervals? Are all the cataclasites seismic or not? If they are seismic, what could be the corresponding earthquake magnitudes?

The evolution of the Nojima fault appears more complex than firstly expected. At least two periods of activity are suspected which are very difficult to decipher from the observation of the drill cores alone. More data are needed on the age of the laumontite or carbonate alteration stages, on the origin of the percolating fluids and on the fluid-rock exchanges. Nevertheless, and even if some questions remain, the GSJ and other drill holes through the Nojima fault represent an important opportunity to study the mechanisms of deformation in active faults and the interactions between fluids and deformation.

Acknowledgments. A.-M. Boullier thanks the organizers of the Second International Symposium on Slip and Flow Processes in and below the Seismogenic Zone for their invitation. The authors are grateful to their colleagues from Japan, France, Switzerland and elsewhere for fruitful discussions during these five years of collaboration. They acknowledge also H. Tanaka and his students for working hard for core handling and preparation of polished sections, T. Nogami and C. Nevado for making high quality thin sections. The constructive review by G. di Toro and the editorial work made by R. Norris improved the paper significantly. This study was financially supported by the CNRS and Ministère des Affaires Étrangères (PICS 1050).

\section{References}

Amitrano, D. and J. Schmittbuhl, Fracture roughness and gouge distribution of a granite shear band, Journal of Geophysical Research, 107, 2375, doi:10.1029/2002JB001761, 2002.

Blenkinsop, T. G., Cataclasis and process of particle size reduction, Pure and Applied Geophysics, 136, 59-86, 1991. 
Blenkinsop, T. G. and R. H. Sibson, Aseismic fracturing and cataclasis involving reaction softening within core material from the Canjon Pass drill hole, Journal of Geophysical Research, 97, 5135-5144, 1992.

Bons, P. D., The formation of veins and their microstructures, in Stress, Strain and Structure, A volume in honour of W. D. Means, vol. 2, edited by M. W. Jessell and J. L. Urai, Journal of Virtual Explorer, 2000.

Boullier, A. M., B. Ildefonse, J. P. Gratier, K. Fujimoto, T. Ohtani, and H. Ito, Deformation textures and mechanisms in the granodiorite from the Nojima Hirabayashi borehole, in International workshop of the Nojima fault core and borehole data analysis, vol. GSJ Interim report No. EQ/00/1, USGS Open-File Report 000-129, edited by H. Ito, K. Fujimoto, H. Tanaka, and D. Lockner, pp. 111-117, Geological Survey of Japan, Tsukuba, Japan, 2000.

Boullier, A. M., T. Ohtani, K. Fujimoto, H. Ito, and M. Dubois, Fluid inclusions in pseudotachylytes from the Nojima fault, Japan, Journal of Geophysical Research Solid Earth, 106, 21965-21977, 2001.

Boullier, A. M., K. Fujimoto, T. Ohtani, G. Roman-Ross, E. Lewin, H. Ito, P. Pezard, and B. Ildefonse, Textural evidence for recent co-seismic circulation of fluids in the Nojima fault zone, Awaji Island, Japan, Tectonophysics, 378, 165-181, 2004.

Fabbri, O., K. Iwamura, S. Matsunaga, G. Coromina, and Y. Kanaori, Distributed strike-slip faulting, block rotation, and possible intracrustal vertical decoupling in the convergent zone of southwest Japan, in Vertical Coupling and Decoupling of the Lithosphere, vol. 227, edited by J. Grocott, B. Tikoff, K. J. W. McCaffrey, and G. Taylor, pp. 141-166, Geological Society of London, Special Publication, 2004.

Fujimoto, K., H. Tanaka, T. Higuchi, N. Tomida, T. Ohtani, and H. Ito, Alteration and mass transfer inferred from the Hirabayashi GSJ drill core penetrating the Nojima Fault, Japan, The Island Arc, 10, 401-410, 2001.

Heilbronner, R., Automatic grain boundary detection and grain size analysis using polarization micrographs or orientation images, Journal of Structural Geology, 22, 969-981, 2000.

James, E. W. and L. T. Silver, Implications of zeolites and their zonation in the Cajon Pass deep drill hole, Geophysical Research Letters, 15, 973 976, 1988.

Kanaori, Y., Late Mesozoic-Cenozoic strike-slip and block rotation in the inner belt of Southwest Japan, Tectonophysics, 177, 381-399, 1990.

Keulen, N., R. Heilbronner, and H. Stünitz, Microstructures and grain size distribution of naturally and experimentally deformed polyphase cataclasites-some preliminary results, in Deformation Mechanisms, Rheology and Tectonics, pp. 93, Saint Malo, France, 2003a.

Keulen, N., R. Heilbronner, A. M. Boullier, and H. Stünitz, What happens after fracturing? Particle size distribution and grain growth in experimentally deformed granitoids, in Swiss Tectonic Studies group, 2003b.

Kitajima, T., Y. Kobayashi, R. Ikeda, Y. Iio, and K. Omura, Terrestrial heat flow in Nojima-Hirabayashi, Awaji Island, Chikyu Monthly, 21, 108113, 1998 (in Japanese).

Means, W. D. and T. Li, A laboratory simulation of fibrous veins: Some first observations, Journal of Structural Geology, 23, 857-863, 2001.

Mizuno, K., H. Hattori, A. Sangawa, and H. Takahashi, Geology of the Akashi district with geological sheet map, Geological Survey of Japan, Tsukuba, 1990 (in Japanese with English abstract).

Monzawa, N. and K. Otsuki, Comminution and fluidization of granular fault materials: Implications for fault slip behavior, Tectonophysics, $\mathbf{3 6 7}$, 127-143, 2003.

Murakami, M. and T. Tagami, Dating pseudotachylyte of the Nojima fault using the fission-track method, Geophysical Research Letters, 31, L12604, doi:10.1029/2004GL020211, 2004.

Murakami, M., T. Tagami, and N. Hasebe, Ancient thermal anomaly of an active fault system: Zircon fission-track evidence from Nojima GSJ $750 \mathrm{~m}$ borehole samples, Geophysical Research Letters, 29(23), 2123, doi:10.1029/2002GL015679, 2002.

Murata, A., K. Takemura, T. Miyata, and A. Lin, Quaternary vertical offset and average slip rate of the Nojima Fault on Awaji Island, Japan, The Island Arc, 10, 360-367, 2001.

Ohtani, T., K. Fujimoto, H. Ito, H. Tanaka, N. Tomida, and T. Higuchi, Fault rocks and past to recent fluid characteristics from the borehole survey of the Nojima fault ruptured in the 1995 Kobe earthquake, southwest Japan, Journal of Geophysical Research, 105, 16161-16171, 2000.

Ohtani, T., H. Tanaka, K. Fujimoto, T. Higuchi, N. Tomida, and H. Ito, Internal structure of the Nojima Fault Zone from the Hirabayashi GSJ drill core, The Island Arc, 10, 392-400, 2001.

Otsuki, K., N. Monzawa, and T. Nagase, Fluidization and melting of fault gouge during seismic slip: Identification in the Nojima fault zone and implications for focal earthquake mechanisms, Journal of Geophysical Research, 108, 2192, doi: 10,1029/2001JB001711, 2003.

Prasher, C., Crushing and Grinding Process Handbook, 474 pp., John Wiley and Sons Ltd, New York, 1987.

Sato, T. and M. Takahashi, Chemical and isotopic compositions of groundwater obtained from the Hirabayashi well, in International workshop of the Nojima fault core and borehole data analysis, vol. GSJ Interim report No. EQ/00/1, USGS Open-File Report 000-129, edited by H. Ito, K. Fujimoto, H. Tanaka, and D. Lockner, pp. 187-192, Geological Survey of Japan, Tsukuba, Japan, 1999.

Scholz, C., The Mechanics of Earthquakes and Faulting, 439 pp., Cambridge University Press, 1990.

Snoke, A. W. and J. Tullis, An overview of fault rocks, in Fault Related Rocks, a Photographic Atlas, edited by A. W. Snoke, J. Tullis, and V. R. Todd, pp. 3-18, Princeton University Press, Princeton, New Jersey, 1998.

Takahashi, Y., K-Ar ages of the granitic rocks in Awaji Island with an emphasis on timing of mylonitization, Journal of Mineralogy, Petrology and Economic Geology, 87, 291-299, 1992.

Takeshita, T. and K. Yagi, Dynamic analysis based on 3-D orientation distribution of microcracks in quartz from the Cretaceous granodiorite core samples drilled along the Nojima fault, southwest Japan, in International workshop of the Nojima fault core and borehole data analysis, vol. GSJ Interim report No. EQ/00/1, USGS Open-File Report 000-129, edited by H. Ito, K. Fujimoto, H. Tanaka, and D. Lockner, pp. 133-140, Geological Survey of Japan, Tsukuba, Japan, 2000.

Tanaka, H., K. Fujimoto, T. Ohtani, and H. Ito, Structural and chemica characterization of shear zones in the freshly activated Nojima fault, Awaji Island, southwest Japan, Journal of Geophysical Research, 106, 8789-8810, 2001.

Vincent, M. W. and P. L. Ehlig, Laumontite mineralization in rocks exposed north of San Andreas fault at Cajon Pass, southern California, Geophysical Research Letters, 15, 977-980, 1988.

Yamaguchi, T., M. Yamano, T. Nagao, and S. Goto, Temperature monitoring in a borehole drilled into the Nojima fault and radioactive heat production of core samples, in International workshop of the Nojima fault core and borehole data analysis, vol. GSJ Interim report No. EQ/00/1, USGS Open-File Report 000-129, edited by H. Ito, K. Fujimoto, H. Tanaka, and D. Lockner, pp. 277-282, Geological Survey of Japan, Tsukuba, Japan, 1999

Yamamoto, Y., H. Kurita, and T. Matsubara, Eocene calcareous nannofossils and dinoflagellate cysts from the Iwaja Formation in Awajishima Island, Hyogo Prefecture, southwest Japan, and their geologic implications, Journal of the Geological Society of Japan, 106, 379-382, 2000.

Zen, E. and A. B. Thompson, Low grade regional metamorphism: Mineral equilibrium relations, Annual Review of Earth and Planetary Sciences, 2, 197-212, 1974

A.-M. Boullier (e-mail: Anne-Marie.Boullier@obs.ujf-grenoble.fr), K. Fujimoto, H. Ito, T. Ohtani, N. Keulen, O. Fabbri, D. Amitrano, M. Dubois, P. Pezard 